\title{
Acute Effects of Lead on Renal Electrolyte Excretion and Plasma Renin Activity ${ }^{1}$
}

\author{
D. R. Mouw, A. J. Vander, Joanne Cox, and Niles Fleischer
}

Department of Physiology, The University of Michigan, Ann Arbor, Michigan 48109

Received October 4, 1977; accepted April 29, 1978

\begin{abstract}
Acute Effects of Lead on Renal Electrolyte Excretion and Plasma Renin Activity. Mouw, D. R., Vander, A. J., Cox, J., AND Fleischer, N. (1978). Toxicol. Appl. Pharmacol. 46, 435447. Since lead accumulates in the kidney and interferes with the renal transport of amino acids and glucose, we tested the hypothesis that acute doses of lead also reduce tubular electrolyte reabsorption and alter the secretion of renin. In sodium pentobarbital-anesthetized dogs, acute iv lead increased the excretion of sodium, potassium, calcium, and water, despite a constant glomerular filtration rate; therefore lead reduced the tubular reabsorption of these substances. Lead also caused an increase in plasma renin activity. The threshold dose of acutely administered lead necessary to elicit these responses was determined in dose-response experiments on unanesthetized rats; a dose of $0.1 \mathrm{mg}$ of lead $/ \mathrm{kg}$ was sufficient to cause significant increases in plasma renin and the renal excretion of sodium. Lead concentrations in the tissues of the rats were measured in samples taken immediately at the conclusion of the study; the threshold dose of lead was associated with very low blood lead $(<5 \mu \mathrm{g} / 100 \mathrm{ml})$ and kidney lead $(1.2 \mu \mathrm{g} / \mathrm{g}$ wet $\mathrm{wt})$. These effects of lead are discussed with regard to their possible clinical significance.
\end{abstract}

Lead is concentrated in the kidneys of lead-exposed mammals and causes hyperaminoaciduria, glycosuria, and hyperphosphaturia - all reflecting decreases in renal tubular reabsorptive processes (Goyer, 1968, 1971b; Hammond, 1972; Hirsch, 1973). Since lead poisoning also impairs mitochondrial function, it is possible that a deficiency of ATP is responsible for the reduction of tubular transport (Goyer et al., 1968; Goyer, 1971a). Since the kidney's major energy-consuming process is reabsorption of sodium, deficient ATP supply might also be expected to reduce this process. Compatible with this hypothesis is the observation that some chronically lead poisoned people are unable to reduce their renal excretion of sodium normally when dietary sodium is restricted (Sandstead et al., 1970; Morgan, 1976).

Lead poisoning may also affect the renin-angiotensin-aldosterone system. People with lead poisoning (most of whom were drinking excess lead-contaminated whiskey) were fed a low $\mathrm{Na}$ diet and were found to have abnormally low plasma renin activity (PRA); however, no measurements of PRA were made while the subjects were on a normal sodium diet (Sandstead et al., 1970; McAllister et al., 1971). Chronic lead poisoning in rabbits fed normal chow causes an increase in the number of juxtaglomerular cells (Ambrosi et al., 1969), increased activity of glucose-6-phosphate

${ }^{1}$ Research supported by NIH Grant No. 1 R01-ESO1141. 
dehydrogenase in the macula densa (DiNunno et al., 1969; Hirsch, 1973), and increased activity of 3-B-ol-dehydrogenase in the adrenal cortex (Strada et al., 1970).

We hypothesized that acute administration of lead would cause natriuresis and alteration of plasma renin in sodium-replete animals, and this hypothesis was tested in anesthetized dogs and unanesthetized rats.

\section{METHODS}

Experiments on anesthetized dogs. Mongrel males weighing $15-20 \mathrm{~kg}$ were anesthetized with sodium pentobarbital, $30 \mathrm{mg} / \mathrm{kg}$ iv, with supplements given as required. The right ureter was exposed via a small flank incision and catheterized with polyethylene (PE) tubing. Arterial blood samples were obtained from a femoral catheter connected to a three-way stop-cock; switching the stop-cock position enabled us to record blood pressure with a Statham pressure transducer and Grass polygraph. Femoral and/or saphenous veins were catheterized for administration of lead and other solutions as described below.

Clearances of creatinine and para-aminohippuric acid (PAH) were used as measures of GFR and RPF, respectively; a prime ( $600 \mathrm{mg}$ of creatinine and $250 \mathrm{mg}$ of PAH in 20 $\mathrm{ml}$ of saline given over $3 \mathrm{~min}$ immediately after surgery) was followed by a constant infusion (creatinine, $6 \mathrm{mg} / \mathrm{min}, \mathrm{PAH}, 1.8 \mathrm{mg} / \mathrm{min}$, in saline at $0.2 \mathrm{ml} / \mathrm{min}$ ). At least $1 \mathrm{hr}$ after surgery, a 1-hr control period was begun; four consecutive 15 -min urine samples were collected and arterial blood samples $(15 \mathrm{ml}$ each) were taken at the midpoint of each urine collection. All blood samples were replaced by an equal volume of dextransaline (Macrodex dextran 70, Pharmacia). After the control period, either lead acetate (experimental group) or sodium acetate (time-control group) was administered iv. The lead prime (in $10 \mathrm{ml}$ of $5 \%$ glucose) was $3 \mathrm{mg}$ of $\mathrm{Pb} / \mathrm{kg}$ (three dogs) or $0.6 \mathrm{mg}$ of Pb/kg (three dogs) and this was followed by a constant infusion delivering $0.2 \mathrm{ml} / \mathrm{min}$ of $5 \%$ glucose containing either 0.5 or $0.1 \mathrm{mg} / \mathrm{min}$ of lead (corresponding to the 3 and $0.6 \mathrm{mg}$ primes). The time-control group (four dogs) was given a prime of sodium acetate $(2.37$ $\mathrm{mg} / \mathrm{kg})$ and constant infusion $(0.382 \mathrm{mg} / \mathrm{min})$ such that the dose of acetate was matched to that received by the experimental group receiving the high dose of lead ( 3 $\mathrm{mg} / \mathrm{kg}$ ). All $\mathrm{Pb}$ and sodium acetate solutions were adjusted to $\mathrm{pH} 7$ with $\mathrm{NH}_{4} \mathrm{OH}$ prior to use. For the next $4 \mathrm{hr}$, two 15-min urine collections, each with an arterial blood sample at its midpoint, were collected during the last $30 \mathrm{~min}$ of each hour.

In one additional lead-treated $\mathrm{dog}(3 \mathrm{mg} / \mathrm{kg}$ dose $)$, the identical protocol was carried out, except that isotonic saline (in addition to that given with the PAH-creatinine) was administered iv beginning at the time of lead administration. The infusion rate was set at approximately twice the concurrent urine flow rate from the right kidney; urine was continuously collected from this kidney, a new collection beginning every $15 \mathrm{~min}$. Changes in total body sodium beginning at the time of lead administration were calculated from the saline infusion rates and the sodium excretion by the right kidney by assuming that sodium excretion was identical for both kidneys. Thus net balance (for the period after lead) equals sodium infused as the vehicle for PAH and creatine plus extra sodium infused (to match urine flow, above) minus sodium excretion of the right kidney $(\times 2)$. 
Experiments on unanesthetized rats. Male Sprague-Dawley rats weighing $250-300 \mathrm{~g}$ and receiving Teklad rat chow and water ad libitum, were used to determine the doseresponse effects of lead on electrolyte excretion and renin. They were conditioned to the experimental protocols on 3 different days just prior to the experiments. Conditioning consisted of our duplicating the entire experimental protocol (except for iv injections and stomach tubes) even to the extent that rats were carried to the (separate) room where the decapitation procedure would be carried out.

In Protocol A, we tested the effect of various iv lead doses on electrolyte and water excretion. Between 8:30 and 9:00 AM, rats were removed from the group cages and injected iv (tail vein) with either lead acetate $(0.02,0.05,0.1$, or $10 \mathrm{mg}$ of $\mathrm{Pb} / \mathrm{kg}$ ) or Naacetate (so that the acetate dosage in these control groups was matched to that of leadtreated animals). All injections were given in $0.25 \mathrm{ml}$ of $5 \%$ glucose vehicle and were flushed in with $0.3 \mathrm{ml}$ of the vehicle. Immediately thereafter, individual animals received distilled water $(5 \mathrm{ml})$ via stomach tube, their bladders were voided manually, and they were placed in metabolic cages; food and water was withheld and urine volume was measured hourly. After $6 \mathrm{hr}$, the bladder was again emptied (this urine was included in the sixth hour collection), and the animals were decapitated. Thereafter, urinary and renal electrolytes and both red cell and kidney lead were analyzed; representative samples of whole kidney were used for analysis.

Protocol B was similar to A, except that this time the lcad-dose/renin responsc relation was evaluated. Renin was not measured in Protocol A since preliminary experiments suggested that renin was elevated (compared to our normal laboratory values for unstressed rats) even in the $\mathrm{Na}$-acetate-treated animals, probably as a result of bladder manipulation. Prior to the day of the experiment, rats were housed individually. At 6 AM on the experimental day, rats were injected as in protocol $A$ and then returned to their home cages; only two lead doses were used $(0.05$ and $0.1 \mathrm{mg} / \mathrm{kg})$. Three hours later [before 9:30 AM, when plasma renin starts to rise as a result of diurnal variation (personal observation)], rats were decapitated and blood was collected. No renin was analyzed for animals showing signs of excitement at decapitation or for animals which appeared to be in ill health (as judged either by weight loss during the 3 days prior to the experiment, or by hematocrits not in the normal range for our laboratory, $40-50 \%$ ).

Analytical methods. Blood samples for renin measurement were anticoagulated using $\left(\mathrm{NH}_{4}\right)_{2}$ EDTA $(0.75 \mathrm{mg} / \mathrm{ml}$ of blood). PRA was measured by radioimmunoassay of angiotensin I (New England Nuclear Kit) generated in vitro during a 60 -min incubation at $37^{\circ} \mathrm{C}$. For dog plasma, the incubation mixture contained plasma $(500 \mu \mathrm{l})$, maleic acid buffer $(2 \mathrm{M}, \mathrm{pH} 5.5,100 \mu \mathrm{l}), \mathrm{BAL}(1.7 \mathrm{~g} / 100 \mathrm{ml}, 10 \mu \mathrm{l})$, and 8-hydroxyquinoline $(6.6 \mathrm{~g} / 100 \mathrm{ml}, 10 \mu \mathrm{l})$. Plasma renin substrate was measured similarly, except that $50 \mu \mathrm{l}$ of plasma, $450 \mu \mathrm{l}$ of saline, and 1 unit of hog renin (Nutritional Biochem) were substituted for $500 \mu \mathrm{l}$ of plasma. The method for rat PRA (Clamage et al., 1976) was similar except that all volumes were reduced 10 -fold and the incubation $\mathrm{pH}$ was 6.5 . Because renin assays do not measure renin directly, but rather measure its ability to generate angiotensin, it was necessary to rule out the possibility that lead would alter the kinetics of the renin-angiotensinogen reaction either by a direct action on renin or angiotensinogen molecules or by alteration of an inhibitor or activator of the chemical reaction. Hog renin $\left(10^{-3}\right.$ units $/ \mathrm{ml}$ of plasma) was added to plasma samples collected 
from each of two different dogs. One sample was taken prior to lead administration and a second sample $3 \mathrm{hr}$ after the beginning of lead administration. The increments in PRA due to the added hog renin were nearly identical for the control and lead-treated plasma I63.5 (dog 1) and $68.8(\operatorname{dog} 2)$ before $\mathrm{Pb}$ vs 67.2 and $51.1 \mathrm{ng} / \mathrm{ml} / \mathrm{hr}$ respectively after $\mathrm{Pb}$. A second test evaluated the possibility that the presence of lead might produce an abnormal discrepancy between in vivo and in vitro PRA; this could conceivably occur

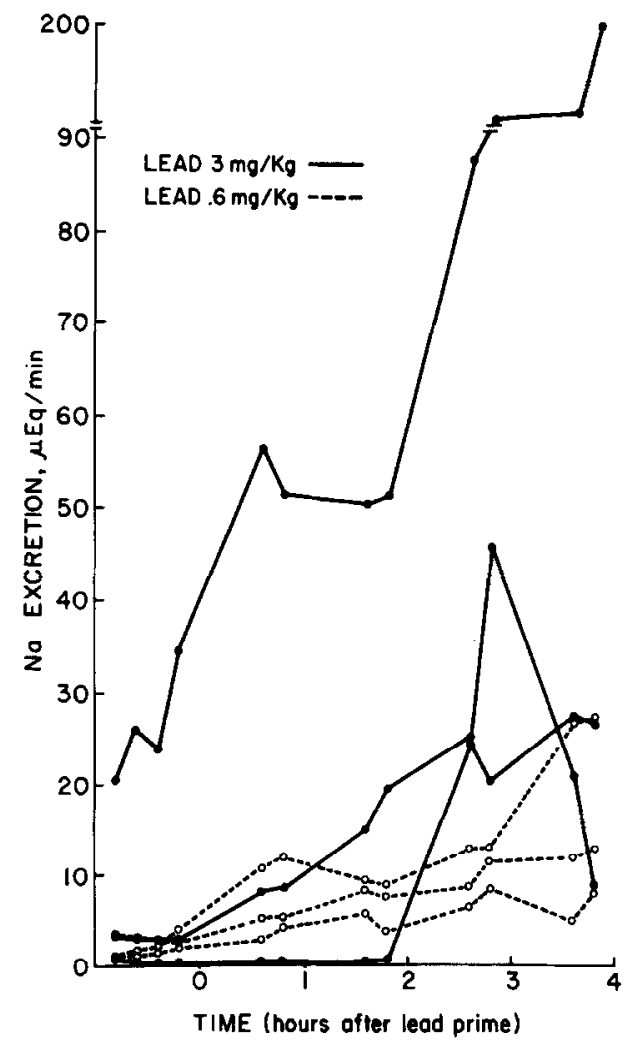

Fig. 1. Effect of lead on renal sodium excrction in individual dogs. Two different doses of lead were used, 3 and $0.6 \mathrm{mg} / \mathrm{kg}$.

since the presence of BAL and EDTA in the in vitro incubation would be expected to lower the free concentration of lead. This possibility was ruled out by performing the in vitro incubation on plasma samples collected using heparin (Liquamen, a brand of heparin which we have previously shown does not bind lead) rather than EDTA, from a dog before and $3 \mathrm{hr}$ after infusing lead; no EDTA or BAL was added to the incubation mixture. As expected there was a small decrease (22\%) in the observed PRA in all samples because of the absence of these inhibitors, but the decrement was the same in the control and lead-treated samples ( 21 and $23 \%$, respectively).

Sodium and potassium in urine, plasma, and kidney tissue were measured by flame photometry on a NIL flame photometer. Lead and calcium in various tissues and urine were measured by atomic absorption methods previously described for our laboratory 
(Mouw et al., 1975). Standard spectrophotometric methods were used to measure creatinine (Bonsnes and Taussky, 1945) and PAH (Smith et al., 1945) in plasma and urine. Hematocrits were read on a micro hematocrit reader subsequent to centrifugation in an International microcapillary centrifuge, Model MB. Results for grouped values are presented as mean \pm SE throughout; Student's $t$ test was used to compare group means and paired samples analysis and Chi-square were employed when appropriate.

\section{RESULTS}

The results of lead on sodium excretion in individual anesthetized dogs are summarized in Fig. 1; in every case lead caused a large increase in sodium excretion. Figure 2 summarizes the changes in urine flow and electrolyte excretion for all control and lead-treated dogs; because the magnitude of the effects of lead on all measured

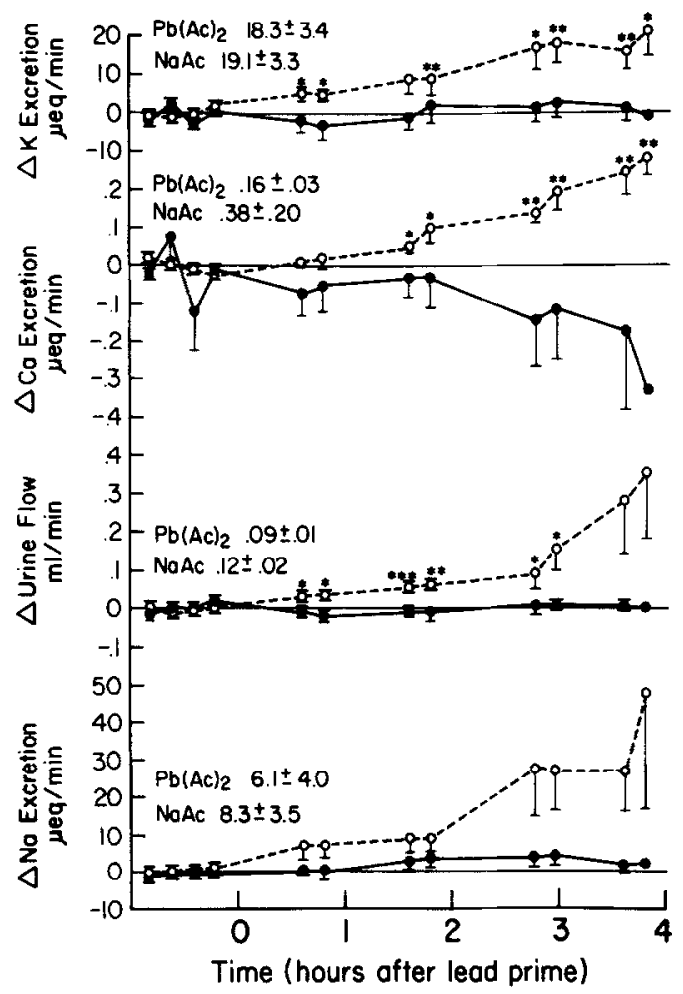

FIG. 2. Effect of lead acetate (six dogs) or sodium acetate (four dogs) on urine flow, and the renal excretion of potassium, calcium, and sodium. For each animal the four control (pre-zero time) values for the variable were averaged and this value was taken as zero on the vertical axis. This (pre-zero-time) value for each animal was subtracted from each individual measurement of that variable for that animal through out the experiment. The points plotted are the means $\pm S E$ of these changes from the pre-zero averages; thus, they represent paired samples analysis with each animal as its own control. Student's $t$ test was used to evaluate the significance of the changes after $\mathrm{Pb}$ acetate $(\mathrm{O}----\mathrm{O})$ or $\mathrm{Na}$ acetate $(\mathrm{O}-\mathrm{O}): *=p<$ $0.05, * *=p<0.01$. The actual numerical values for the two groups during the pre-zero period are given at the left of the panel for that variable (there were no significant differences between the groups during the pre-zero time period). 
variables was not significantly different for the two $\mathrm{Pb}$ doses, and because no lead doseresponse study was done in the dog experiments, the results for both doses have been pooled. The mean increase in sodium excretion by the fourth hour was approximately sevenfold; however, the great variability in the absolute magnitude of the individual responses (Fig. 1) resulted in $p$ values of only borderline statistical significance ( $p=$ 0.06 or 0.07 for five of the last six urine collections). However, Chi-square analysis of the data in terms of the directional change (up or down) in sodium excretion yielded $p$ values of $<0.01$ for all of the six final urine collections when lead-treated dogs were compared with time controls (only one or two of the four time controls manifested an increase during any of these periods). Lead caused significant increases in urine flow, potassium excretion, and calcium excretion; there were no changes in the excretion of these substances in the control group.

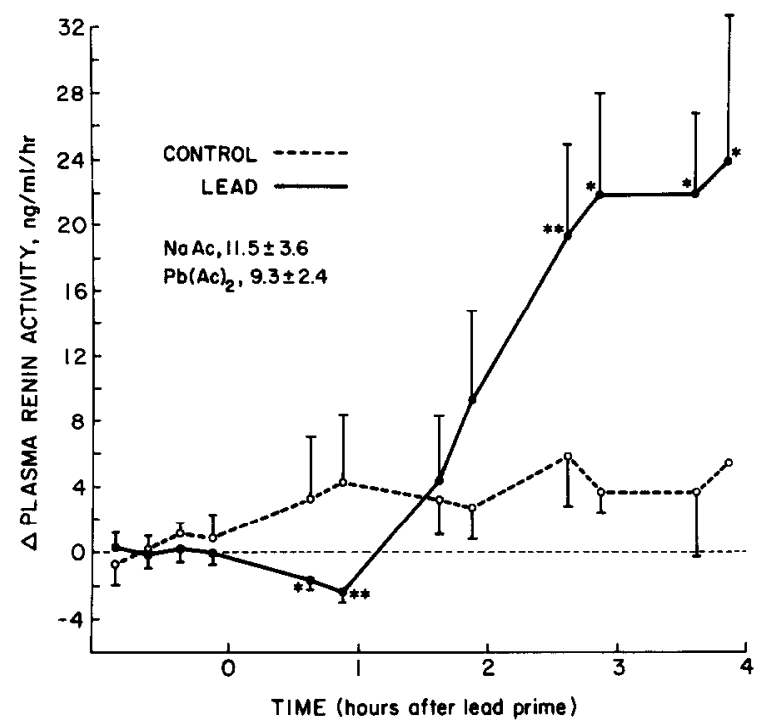

FIG. 3. Effect of lead acetate $(n=6)$ or sodium acetate $(n=4)$ on arterial plasma renin activity in dogs. See Fig. 2 for a description of data presentation. $*=p<0.05, * *=p<0.01$.

PRA (Fig. 3) remained stable in the control group, but was first reduced and then greatly increased by lead treatment. Lead treatment $(3 \mathrm{mg} / \mathrm{kg})$ caused no change in plasma renin substrate; the value during the control period for three dogs was 1061 $\pm 24.0 \mathrm{ng} / \mathrm{ml} / \mathrm{hr} ; 3 \mathrm{hr}$ after lead, it was $1026 \pm 48.3 \mathrm{ng} / \mathrm{ml} / \mathrm{hr}$.

Figure 4 summarizes renal hemodynamics and systemic blood pressure for control and lead-treated groups; there were no changes between or within groups. No detectable changes in hematocrit or plasma electrolytes occurred over the course of the experiment in either group, nor were there any significant differences between groups.

Figure 5 illustrates the effect of lead $(3 \mathrm{mg} / \mathrm{kg}$ ) on PRA and renal sodium excretion in the one animal maintained in positive sodium balance (see Methods and bottom panel of Fig. 5) during the period after lead administration. The effect of lead on PRA was indistinguishable from that observed in the larger group of animals (Fig. 3) in which sodium losses were not replaced. 
Administration of lead acetate iv to unanesthetized rats (Protocol A) caused a doserelated increment in the total amount of sodium excreted during $6 \mathrm{hr}$; the lowest dose producing a significant increment was $0.1 \mathrm{mg} / \mathrm{kg}$ (Fig. 6). Sodium losses at shorter time intervals (Fig. 7) also showed a similar dose-response relation; the natriuretic responses became pronounced as early as $2 \mathrm{hr}$ after lead. Over the 6 -hr collection we observed

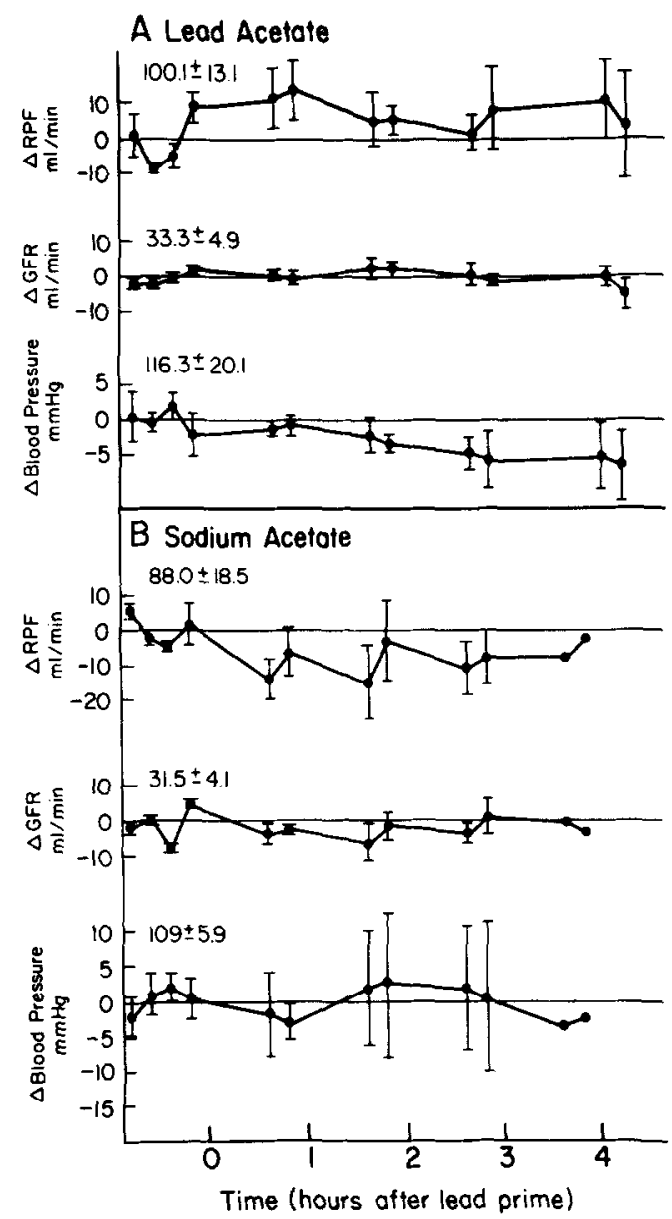

FIG. 4. Effect of lead acetate $(A, n=6)$ or sodium acetate $(B, n=4)$ on renal plasma flow (RPF), glomerular filtration rate (GFR), and mean arterial blood pressure in dogs. See Fig. 2 for a description of data presentation.

similar dose-related increments in urine flow and potassium excretion (Fig. 6). Calcium excretion was elevated at the two highest doses, but the dose-response relation was less clear-cut (Fig. 6). Renal tissue electrolytes were unaltered by lead; in kidneys from animals receiving $1 \mathrm{mg} / \mathrm{kg}$ of lead (a dose which caused a large increase in $\mathrm{Na}^{+}, \mathrm{K}^{+}$, $\mathrm{Ca}^{2+}$, and water excretion, see Fig. 6), lead treated (L) and control (C) animals had equal renal tissue concentrations $(\mu \mathrm{M} / \mathrm{g}$ wet wt. $)$ of $\mathrm{Na}^{+}(\mathrm{L}=53.4 \pm 1.75, \mathrm{C}=55.1 \pm$ $3.46), \mathrm{K}^{+}(\mathrm{L}=73.4 \pm 2.06, \mathrm{C}=69.4 \pm 2.49)$, and $\mathrm{Ca}^{2+}(\mathrm{L}=3.74 \pm 0.19, \mathrm{C}=3.59 \pm$ 0.24). Intravenous lead also produced increments in PRA in unanesthetized rats. Lead, 


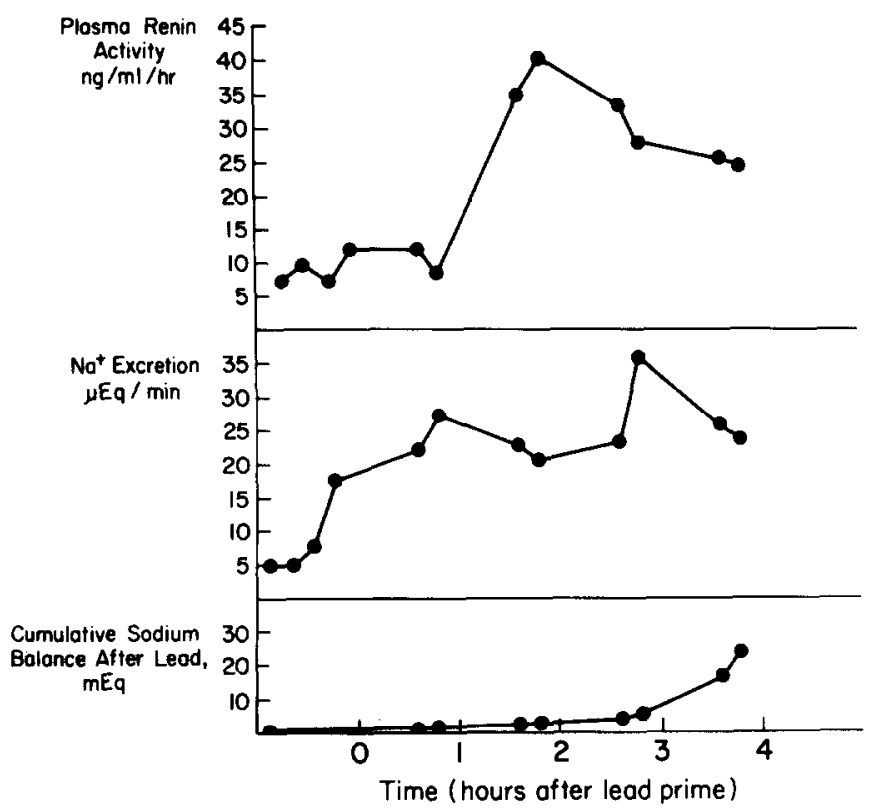

Fig. 5. Effect of lead ( $3 \mathrm{mg} / \mathrm{kg}$ ) on plasma renin activity and renal sodium excretion in a dog maintained in positive sodium balance subsequent to lead administration.

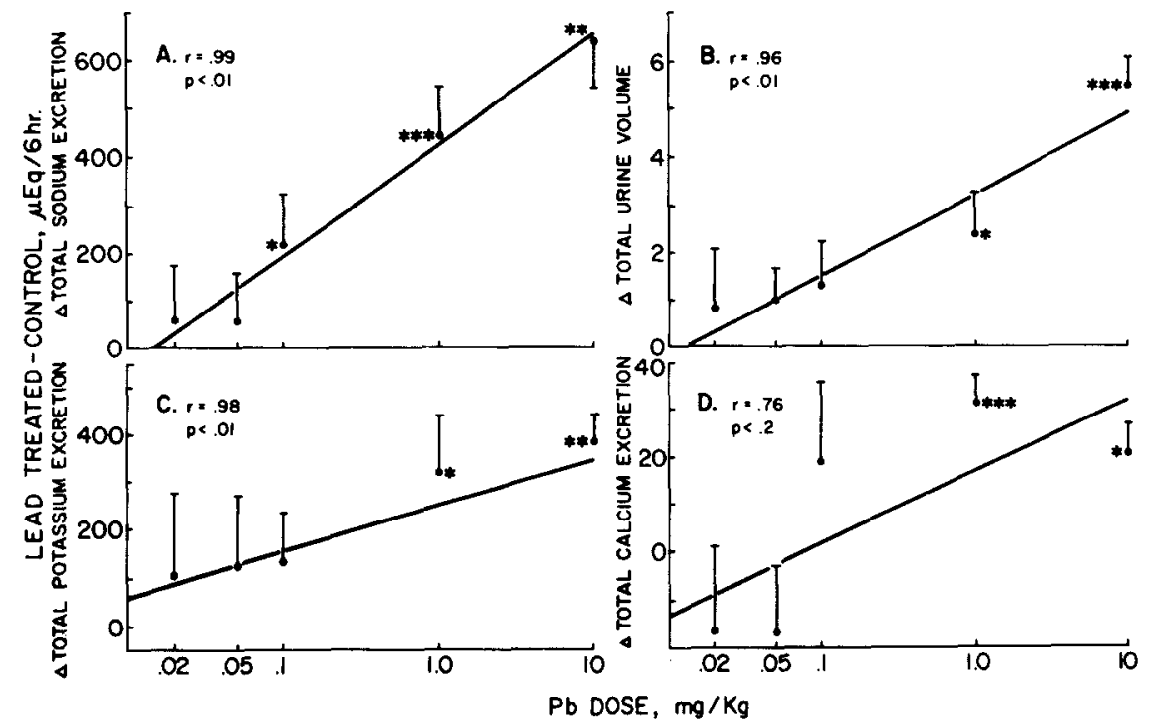

Fig. 6. Effect of various doses of lead on sodium, potassium, calcium, and water excretion over a 6-hr period in rats. The ordinate indicates the mean difference ( \pm combined SE) between the sodium excretion of the lead-treated animals and that of the same-day control animals. Mean 6-hr values for all 29 control

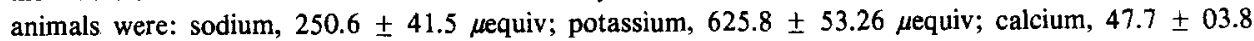
$\mu$ quiv; and water, $3.23 \pm 0.347 \mathrm{ml}$. Significant differences (Student's $t$ test using paired-samples analysis) between control and experimental groups are indicated by asterisks: $*=p<0.05 ; * *=p<0.01 ; * * *=$ $p<0.001$. 
$0.1 \mathrm{mg} / \mathrm{kg}$, raised PRA (ng $/ \mathrm{ml} / \mathrm{hr}$ ) from $6.98 \pm 0.85$ (control, $n=5$ ) to $11.91 \pm 1.54(n$ $=5, p<0.02)$; the only other dose of lead tried $(0.05 \mathrm{mg} / \mathrm{kg}$ ) was ineffective (control $=$ $7.31 \pm 0.78$, experimental $=6.10 \pm 0.43$ ). Kidney and red cell lead concentrations were elevated in the lead-treated rats of Protocol A. After lead doses (mg/kg) of $0.1,1$, and

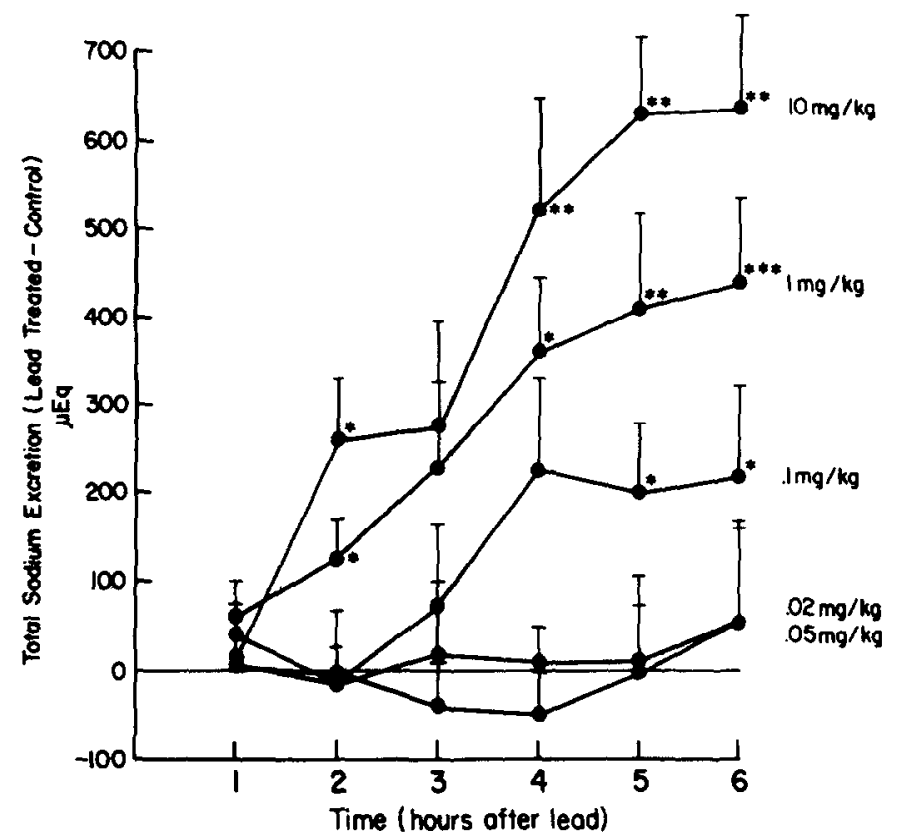

FIG. 7. Cumulative sodium excretion at various times after lead administration in rats. Each line represents the time course of the lead-induced natriuresis for a different dose of lead. Ordinate and $p$ values are as in Fig. 6.

10, kidney lead $(\mu \mathrm{g} / \mathrm{g}$ wet wt) was $1.2 \pm 27(n=6), 11.4 \pm 1.04(n=9)$, and $59.6 \pm$ $9.47(n=6)$, respectively. For the same groups, red cell lead $(\mu \mathrm{g} / 100 \mathrm{ml})$ was $<10,120$ $\pm 25(n=5)$, and $1130 \pm 196(n=5)$.

\section{DISCUSSION}

These experiments demonstrate that acute administration of lead causes increased urinary excretion of sodium, potassium, calcium, and water in both dogs and rats. In the former, these occurred with no change in the plasma concentrations of the substances or in GFR; accordingly, at least in dogs, the effects must be on renal tubular transport mechanisms. In addition, acute lead causes a transient decrease in PRA followed by a prolonged increase.

The mechanism by which lead affects water and electrolyte excretion may be secondary to an effect of lead on mitochondria (Goyer et al., 1968; Goyer, 1971a) such that deficient ATP supplies may impair active transport mechanisms. Alternatively, lead might alter tubular permeability or it might interfere with carrier molecules or enzymes, e.g., $\mathrm{Na} / \mathrm{K}$ ATPase (Siegel et al., 1976; Hasan et al., 1967), specifically involved in tubular transport. Chronic lead poisoning in humans does reduce red cell ATPase 
activity (Hasan et al., 1967), and lead (in low concentrations) inhibits a variety of enzymes in vitro (Vallee and Ulmer, 1972). Inhibition of renal ATPase would reduce tubular reabsorption of sodium and such a primary inhibition of sodium reabsorption, particularly in the proximal tubule, could lead in turn to increased excretion of calcium, potassium, and water, since the renal tubular transport of these substances is closely coupled to that of sodium (Giebisch, 1969; Massry and Coburn, 1973). If renal $\mathrm{Na} / \mathrm{K}$ ATPase were grossly inhibited, one would expect cellular $\mathrm{Na}^{+}$to rise and cellular $\mathrm{K}^{+}$to fall in kidneys; in a dose $(1 \mathrm{mg} / \mathrm{kg})$ which caused large changes in electrolyte excretion, lead failed to alter whole-kidney $\mathrm{Na}$ and $\mathrm{K}$. However, it is possible that both intracellular and extracellular $\mathrm{Na}$ and $\mathrm{K}$ concentrations in the kidney were altered by lead such that whole kidney lead remained constant. Thus, the role of ATPase inhibition and the general mechanism for the lead effect on electrolyte excretion remain unclear.

What are the possible mechanisms for the effect of lead on PRA? Since PRS was unchanged, the change in PRA actually reflects a change in plasma renin concentration. Moreover, it is also very likely that this change is due to increases in renin secretion, since the rapidity of the rise in PRA argues strongly against changes in the hepatic degradation of renin being a major factor (Heacox et al., 1967). The mechanism by which lead stimulates renin secretion cannot be determined from these experiments, but two facts argue against it being only due to volume depletion secondary to lead-induced natriuresis. First, the amounts of sodium lost during the first $2 \mathrm{hr}$ after lead, i.e., prior to the rapid rise in PRA, are very small compared to those we have previously shown to be required for rise in PRA in the anesthetized dog (Vander and Luciano, 1967); second, in one animal, maintained in positive sodium balance after lead administration (Fig. 5), lead still produced a marked increase in PRA.

Others have concluded that lead administered ip had no effect on PRA in rats (Perry and Erlanger, 1973). However, in that study, the mean PRA was actually elevated by approximately 50\% after lead, but the very large SE (perhaps due to the fact that samples were taken just 5 min after anesthesia, when PRA is rising rapidly), and the small number of animals, resulted in a nonsignificant $p$ value. There have been several reports of the effect of other heavy metals on renin release. Chronic ingestion or acute (ip) administration of cadmium acetate in rats elevated PRA (Perry and Erlanger, 1973) and increased the juxtaglomerular index (Chiappino and Baroni, 1969). Since the acute effect of cadmium is antinatriuresis (Vander, 1962), it is possible that cadmiuminduced renin secretion is secondary to a decrease in macula densa sodium load (Vander, 1967). Mecurials also stimulate renin release, but this effect appears to be secondary to volume depletion (Vander and Luciano, 1967; Vander, 1967; Meyer et al., 1966).

A major question concerns the significance of these effects on electrolyte and renin metabolism for human health. The upper limit of the dose threshold for the effects on sodium excretion and renin was $0.1 \mathrm{mg} / \mathrm{kg}$. For that dose, whole blood lead concentration at the conclusion of the experiment was $<5 \mu \mathrm{g} / 100 \mathrm{ml}$. This concentration is lower than that seen either in the general human population $(10-15 \mu \mathrm{g} / 100 \mathrm{ml})$ or in wild rats in the natural environment (Mouw et al., 1975). However, blood lead concentrations were certainly much higher immediately after injection; assuming all the injected lead is initially distributed in the blood, and blood volume $=7 \%$ of body weight, 
the initial blood leads would be $142 \mu \mathrm{g} / 100 \mathrm{ml}$ for the $0.1 \mathrm{mg} / \mathrm{kg}$ dose. Moreover, plasma or ultrafilterable lead in blood was undoubtedly very high after the initial injection of lead. Since, after an iv injection of lead, blood lead concentration decreases rapidly with time while total kidney lead is similar at 1 and 6 or $12 \mathrm{hr}$ after an iv injection (Castellino and Aloj, 1964, 1969), it is perhaps more reasonable to use renal lead as an in vivo index of the dose magnitude since renal lead at the conclusion of the experiment ( $6 \mathrm{hr}$ after iv injection) would indicate the level which produced the experimental effects between 1 and $6 \mathrm{hr}$ after lead. Renal lead content for the $0.1 \mathrm{mg} / \mathrm{kg}$ dose was $1.2 \mu \mathrm{g} / \mathrm{g}$ whereas "normal" humans have renal concentrations of about $0.5-0.7$ $\mu \mathrm{g} / \mathrm{g}$ (Barry, 1975; Morgan, 1972), and wild rats in the natural environment have about $1-40 \mu \mathrm{g} / \mathrm{g}$ (Mouw et al., 1975). It is of course possible that the location of lead within the kidney in chronic lead poisoning may render it less toxic than our acute doses. Thus, in order to further ascertain whether these effects of lead on electrolyte excretion have clinical significance for the general population, lead will have to be administered chronically in the diet of animals.

In light of our findings that lead stimulates renin release, it is surprising that severely lead poisoned humans have been reported to have inappropriately low PRA when on a low sodium diet plus diuretic therapy, and that this deficit was corrected when the lead poisoning was treated with EDTA chelation therapy (Sandstead et al., 1970; McAllister et al., 1971); again, experiments will be needed to elucidate the reason for this apparent inconsistency.

In contrast to the renin data, our finding of inhibition of sodium reabsorption is consistent with clinical reports that lead poisoned patients are unable to lower sodium excretion quickly when dietary sodium is suddenly reduced (sodium wasting) (Sandstead et al., 1970; Morgan, 1972). Finally, lead has been postulated to play a role in human hypertension (Diaz-Rivera and Horn, 1945; Beevers et al., 1976), and the stimulatory effect of lead on renin observed in our experiments would be compatible with such a hypothesis.

\section{ACKNOWLEDGMENTS}

The authors gratefully acknowledge the technical assistance of Ken Kalitis and Sandra Schock.

\section{REFERENCES}

Ambrosi, L., Vimercati, F., DiNunno, C., and DeStasio, G. (1969). Aspetti istologici dell'apparato iuxtaglomerulare nel saturnismo sperimentale. Med. Lav. 60, 118-125.

BARRY, P. S. I. (1975). A comparison of concentrations of lead in human tissues. Brit. J. Ind. Med. 32, 119-140.

Beevers, D. G., Erskine, E., AND Robertson, M. (1976). Blood-lead and hypertension. Lancet 2, 1-8.

BoNSNES, R. W., AND TAUSSKY, H. H. (1945). On the colorimetric determination of creatinine by the Jaffe reaction. J. Biol. Chem. 158, 581-591.

Castellino, N., AND Aloj, S. (1964). Kinetics of the distribution and excretion of lead in the rat. Brit. J. Indust. Med. 21, 308-314.

CAstellino, N., AND Aloj, S. (1969). Intracellular distribution of lead in the liver and kidney of the rat. Brit. J. Indust. Med. 20, 139-143. 
Chiappino, G., and Baroni, M. (1969). Segni morfologici di iperattivita del sistema renina-aldosterone nella ipertensione sperimentale de cadmio. Med. Lav. 60, 297-305.

Clamage, D. M., Sanford, C. S., Vander, A. J., and Mouw, D. R. (1976). Effects of psychosocial stimuli on plasma renin activity in rats. Amer. J. Phys. 231, 1290-1294.

Diaz-Rivera, R. S., AND Horn, R. C., JR. (1945). Postmortem studies in hypertensive rats chronically intoxicated with lead acetate. Proc. Soc. Exp. Biol. Med. 59, 161-163.

Dinunno, C., Vimercati, F., DeStasio, G., Ambrosi, L., and Strada, L. (1969). L'Attivita glucosio-6-fosfato deidrogenasica delle cellule della macula densa nel saturnismo sperimentale. Med. Lav. 60, 343-346.

GIEBISCH, G. (1969). Functional organization of proximal and distal tubular electrolyte transport. Nephron 6, 260-281.

Goyer, R. A. (1968). The renal tubule in lead-poisoning. I. Mitochondrial swelling and aminoaciduria. Lab. Invest. 19, 71-77.

GoYer, R. A. (1971a). Lead toxicity: A problem in environmental pathology. Amer. J. Pathol. 64, 167-190.

GOYER, R. A. (1971b). Lead and the kidney. Curr. Top. Pathol. 55, 147-176.

Goyer, R. A., Krall, A., AND Kimball, J. P. (1968). The renal tubule in lead-poisoning. II. In vitro studies of mitochondrial structure and function. Lab. Invest. 19, 78-83.

Hammond, P. B. (ed.). (1972). Airborne Lead in Perspective. NRC, NAS, Washington, D.C.

Hasan, J., VikKo, V., and HenaberG, S. (1967). Deficient red cell membrane sodiumpotassium ATPase in lead poisoning. Arch. Env. Health 14, 313-318.

Heacox, R., Harvey, A. M., AND Vander, A. J. (1967). Hepatic inactivation of renin. Circ. Res. 31, 149-152.

HiRsch, G. H. (1973). Effect of chronic lead treatment on renal function. Toxicol. Appl. Pharmacol. 25, 84-93.

MASSRY, S. G., AND CoBuRn, J. W. (1973). The hormonal and non-hormonal control of renal excretion of calcium and magnesium. Nephron 10, 66-112.

MCAllister, R. G., Michelakis, A. M., AND Sandstead, H. H. (1971). Plasma renin activity in chronic plumbism. Arch. Intern. Med. 127, 919-923.

Meyer, P., Menard, J., Alexandre, J. M., ANd Weil, B. (1966). Correlations between plasma renin, hematocrit, and natriuresis. Rev. Canad. Biol. 25, 111-121.

Morgan, J. M. (1972). "Normal" lead and cadmium content of the human kidney. Arch. Env. Health. 24, 364, 368.

MoRGaN, J. M. (1976). Hyperkalemia and acidosis in lead nephropathy. South Med. J. 69, 881886.

Mouw, D. R., Kalitis, K., Anver, M., Schwartz, J., Constan, A., Cohen, B., Hartung, R., AND Ringler, A. (1975). Lead: Possible toxicity in urban vs. rural rats. Arch. Env. Health. 30, 276-280.

Perry, H. M., AND Elanger, M. W. (1973). Elevated circulating renin activity in rats following doses of cadmium known to induce hypertension. J. Lab. Clin. Med. 82, 399-405.

Sandstead, H. H., Michelakis, A. M., and Temple, T. E. (1970). Lead intoxication: Its affects on the renin-aldosterone response to sodium deprivation. Arch. Env. Health 20, 356363.

Siegel, G. J., Fogt, S. K., AND HuRley, M. J. (1976). Lead actions on sodium plus potassiumactivated adenosine triphosphatase from electroplax, rat brain, and rat kidney. 9th Rochester International Conference on Environmental Toxicity. Plenum Press, New York.

Smith, H. W., Finkelstein, N., Aliminosa, L., Crawford, B., and Graber, M. (1945). The renal clearances of substituted hippuric acid derivatives and other aromatic acids in dog and man. J. Clin. Invest. 24, 388-404.

Strada, L., LoStorto, A., Dinunno, C., L’Abbate, N., and Ambrosi, L. (1970). Rilievi istochimici sull'attiviti dello steroide 3 ol-deidrogenasi nella zona glomerularc del surrene in corso di saturnismo sperimentale. Med. Lav. 61, 548-551.

VALLEE, B. L., AND Ulmer, D. D. (1972). Biochemical effects of mercury, cadmium and lead. Annu. Rev. Biochem. 41, 91-128. 
VANDER, A. J. (1962). Effect of cadmium on renal tubular sodium transport. Amer. J. Physiol. 203, 1-5.

VANDER, A. J. (1967). Control of renin release. Physiol. Rev. 47, 359-410.

VANDER, A. J., A.ND Luciano, J. R. (1967). Effects of mercurial diuresis and acute sodium depletion on renin relase in dog. Amer. J. Physiol. 212, 651-656. 